\title{
Effects of pH-treated Fish Sarcoplasmic Proteins on the Functional Properties of Chicken Myofibrillar Protein Gel Mediated by Microbial Transglutaminase
}

\author{
Bung-Orn Hemung ${ }^{1}$ and Koo Bok Chin* \\ Department of Animal Science and Functional Foods Research Institute, College of Agriculture and Life Science, \\ Chonnam National University, Gwangju 500-757, Korea \\ ${ }^{1}$ Faculty of Applied Science and Engineering, Khon Kaen University, Nong Khai Campus, Nong Khai, Thailand, 43000
}

\begin{abstract}
$\mathrm{pH}$ adjustment would be of advantage in improving the water holding capacity of muscle proteins. The objective of this study was to evaluate the addition of fish sarcoplasmic protein (SP) solution, which was adjusted to $\mathrm{pH} 3.0$ or 12.0 , neutralized to $\mathrm{pH} 7.0$, and lyophilized to obtain the acid- and alkaline-treated SP samples, on the functional properties of the chicken myofibrillar protein induced by microbial transglutaminase (MTG). The solubility of alkaline-treated SP was higher than that of the acid counterpart; however, those values of the two $\mathrm{pH}$-treated samples were lower than that of normal SP $(p<0.05)$. All SP solutions were mixed with myofibrillar proteins (MP) extracted from chicken breast, and incubated with MTG. The shear stresses of MP with acid- and alkaline-treated SP were higher than that of normal SP. The thermal stability of MP mixture reduced upon adding SP, regardless of the $\mathrm{pH}$ treatment. The breaking force of MP gels with acid-treated SP increased more than those of alkaline-treated SP, while normal SP showed the highest value. The MP gel lightness increased, but cooking loss reduced, with the addition of SP. Smooth microstructure of the gel surface was observed. These results indicated that adjusting the $\mathrm{pH}$ of SP improved the water holding capacity of chicken myofibrillar proteins induced by MTG.
\end{abstract}

Key words: fish sarcoplasmic proteins, acid and alkaline treatments, microbial transglutaminase, cooking loss, chicken myofibrillar protein

\section{Introduction}

Muscle sarcoplasmic proteins (SP) contain several pigments and enzymes involving in the glycolytic pathway. Since they are water soluble proteins, they are washed out easily with water. Currently, fish SP solution is normally washed out from the surimi processing since they may cause the deterioration of surimi during storage. This amount of washed water is drained out as a waste causing the big burden on waste management. However, the washed water has been considered as the protein solution, particularly SP, and should be recovered for being the valuable ingredient. Recovery of SP for $1.7 \mathrm{~kg}$ from every $100 \mathrm{~kg}$ of surimi production has been reported (Lin et al., 1995). The functional properties of SP from oil sardine (Sardinella longiceps) have been investigated (Karthike-

\footnotetext{
*Corresponding author: Koo Bok Chin, Department of Animal Science, Chonnam National University, Gwangju 500-600, Korea. Tel: +82-62-530-2121, Fax: +82-62-530-2129, E-mail: kbchin@jnu.ac.kr
}

yan et al., 2004). Application of SP as a food additive in fish protein gel has been intensively discussed since it improved textural properties of fish protein gel and surimi (Kim et al., 2005). Emulsifying properties of SP was also improved by chemical modifications (Krasaechol et al., 2008). However, such chemicals might be limited for food application. Water holding capacity improved with the addition of fish SP. Direct application of fish SP powder in the protein gel system resulted in an increase the cooking yield, while the gel strength was reduced (Hemung and Chin, 2013). Such phenomenon was partially due to the increases thermal stability of fish MP by interaction with fish SP. However, interactions between fish SP and other meat protein have not been investigated, especially in chicken meat. Therefore, effects of SP on the gelling properties of chicken proteins should be investigated with the reduced salt concentration when microbial transglutaminase (MTG) is used to induce gelation.

MTG is the cross-linking enzyme and has been isolated from Streptoverticillium sp. (Ando et al., 1989). It cata- 
lyzes the acyl transfer reaction from the glutamine-bound proteins to the lysine-bound proteins, resulting in the protein cross-linking through the formation of the isopeptide bond ( $\varepsilon$-( $\gamma$-glutamyl)-lysine) (Folk, 1980). MTG is also available as a commercial enzyme and has been used to improve textural properties of chicken protein (RuizCarrascal and Regenstein, 2002). This was because chicken myofibrillar protein is not much strong as pork and beef (Ahhmed et al., 2009). Although MTG was applied to improve textural properties, higher cooking loss of protein gel has been observed, as compared to those without MTG (Hong and Chin, 2010). Thus, addition of the waterholding agent would be the way to overcome the drawback of MTG application. Hydrocolloids and by-products from dairy processing have been used as the water holding agents in MTG-mediated protein gels (Pietrasik et al., 2007). Thus, application of fish SP as water holding agent would be possible. In addition, subjecting SP to acid or alkaline treatments improved water holding capacity of SP (Yongsawatidgul and Hemung, 2010). Therefore, the objective of this study was attempted to investigate the properties of chicken myofibrillar protein mixture/gel mediated by MTG as affected by fish SP and its $\mathrm{pH}-$ treatment.

\section{Materials and Methods}

\section{Sample preparation}

A live fish, red sea bream (Pagrus major), with the size about $1 \mathrm{~kg}$ were caught from Gunnae-ri, Dolsan-eup, Yeosu-si, Jeollanam-do, Korea, killed and transported to the Meat Science Laboratory, Chonnam National University, South Korea, within 20 min. Fish samples were manually filleted and prepared fish flesh as fish cubes, which were mixed, divided $\left(200 \mathrm{~g} /\right.$ each) before keeping at $-70^{\circ} \mathrm{C}$ under the vacuum condition until used.

Chicken breast samples with the weight about $120 \mathrm{~g} /$ each were trimmed to remove the connective tissue before cutting into the cubic shape. The chicken breast cubes were mixed before dividing into $200 \mathrm{~g} /$ portion. All samples were kept under vacuum condition at $-20^{\circ} \mathrm{C}$ until utilized. Microbial transglutaminase (1\%, MTG, TG-S) was obtained from the Ajinomoto Korea Inc. (Korea).

\section{Fish SP preparation}

After thawed in a cold room overnight, the frozen fish cubes were homogenized for 2 min with 3 times of deionized water (DI-water) using blender and centrifuged for $15 \mathrm{~min}$ at $1,000 \times \mathrm{g}$. Then, the supernatant was col- lected and divided into 3 portions. The first portion was directly lyophilized using freeze-dryer (IlShin Lab Co, Ltd., Korea) to use as a normal SP powder. The other 2 portions were adjusted the $\mathrm{pH}$ to be 3.0 or 12.0 , and neutralized both samples to $\mathrm{pH} 7.0$ using either $3 \mathrm{~N} \mathrm{HCl}$ or $\mathrm{NaOH}$, according to Yongsawatdigul and Hemung (2010). The neutralized SP samples were lyophilized to obtain the powders and used as an acid-or alkaline-treated SP, respectively.

\section{Chicken MP preparation}

MP was extracted from chicken breast according to the method of Xiong (1993) with slight modifications. Chicken breast cubes were thawed and blended with 4 volumes of washing buffer $(0.1 \mathrm{M} \mathrm{NaCl}, 50 \mathrm{mM}$ phosphate buffer, $\mathrm{pH}$ 6.25) for $2 \mathrm{~min}$ using blender. The homogenate was centrifuged at $1,000 \times \mathrm{g}$ for $15 \mathrm{~min}$ at $4^{\circ} \mathrm{C}$ before collecting only pellet and that pellet was washed twice. The obtained pellet was re-suspended with 8 volumes of 0.1 $\mathrm{M} \mathrm{NaCl}$ solution (adjusted $\mathrm{pH}$ to 6.25 ) prior removal of connective tissue by filtering through 2 layers of gauze. The filtrate was centrifuged at $1,000 \times \mathrm{g}$ for $15 \mathrm{~min}$ and the pellet was collected for being chicken MP. The MP pellet was measured moisture content (\%) according to AOAC method (AOAC, 2000). Protein concentration in MP pellet was estimated by Biuret method (Gornall et al., 1949) and bovine serum albumin was used as protein standard.

\section{Solubility test of SP powders and chicken MP}

SP powders $(0.1 \mathrm{~g})$ were mixed with $10 \mathrm{~mL}$ of phosphate buffer $(0.30 \mathrm{M} \mathrm{NaCl}, 50 \mathrm{mM}$ phosphate buffer $\mathrm{pH}$ 6.25) before shaking at room temperature for $10 \mathrm{~min}$. Then, all samples were centrifuged at $3000 \mathrm{~g}$ for $15 \mathrm{~min}$. The supernatant was collected for determining the protein content by the Biuret method as described previously. Solubility of SP was expressed as protein concentration $(\mathrm{mg} / \mathrm{mL})$ in the supernatant.

Chicken MP $(1 \mathrm{~g})$ was mixed with $10 \mathrm{~mL}$ of phosphate buffer $(50 \mathrm{mM}$ phosphate buffer $\mathrm{pH}$ 6.25) containing different concentration ( $0-0.9 \mathrm{M})$ of $\mathrm{NaCl}$ before centrifugation at $3,000 \times \mathrm{g}$ for $15 \mathrm{~min}$. Protein concentration $(\mathrm{mg} /$ $\mathrm{mL}$ ) in the supernatant was determined to represent the solubility.

\section{Chicken MP mixture/gel preparation}

Chicken MP was controlled at $4 \%$ in the $\mathrm{NaCl}$ content of $0.3 \mathrm{M}$ at $\mathrm{pH} 6.25$. Effects of SP powders were evaluated at $0.5 \%$ and MTG was added to all samples for $0.5 \%$. The reaction mixture was applied into the glass vial $(\varnothing=$ 
$12 \mathrm{~mm}$ ) for $5 \mathrm{~g}$ per each and incubated at $4^{\circ} \mathrm{C}$ for $6 \mathrm{~h}$. All samples were heated from room temperature $\left(\approx 20^{\circ} \mathrm{C}\right)$ to $80^{\circ} \mathrm{C}$ at the heating rate of about $3^{\circ} \mathrm{C} / \mathrm{min}$. The cooked MP samples were rapidly cooled in an ice mixed water, kept in the cold room overnight prior performing MP gel analysis.

\section{Rheological analysis}

Chicken MP mixture was prepared with the same manner with MP gel preparation. The rheological properties of sample, incubated at $4^{\circ} \mathrm{C}$ for $6 \mathrm{~h}$, were tested using a rotational rheometer ( $\mathrm{RC} 30$, Rheotec Messtechnik $\mathrm{GmbH}$, Germany). The probe, bob $\left(120^{\circ} \mathrm{C}\right)$ and cup, with the radii probe of 7 and $7.59 \mathrm{~mm}$, respectively, was used. All samples were sheared up to $1200 \mathrm{1} / \mathrm{s}$. The shear stress values were recorded and a function of shear rate.

\section{Differential scanning calorimetry (DSC)}

After differential scanning calorimeter (DSC S-650, Scinco Co. Ltd., Korea) was calibrated with indium standard, it was used to determine the thermal properties of chicken MP mixtures, which were incubated at $4{ }^{\circ} \mathrm{C}$ for $6 \mathrm{~h}$. Approximately $15 \mathrm{mg}$ of MP sample was weighed and it was encapsulated in the aluminum pan before heating from room temperature to $100^{\circ} \mathrm{C}$ at the heating rate of $10^{\circ} \mathrm{C} / \mathrm{min}$. An encapsulated empty was run as the reference of the analysis. The endothermic heat flow and sample peaks were recorded.

\section{Sodium dodecyl sulfate polyacrylamide gel electro- phoresis (SDS-PAGE)}

MP mixture with SP, incubated at $4^{\circ} \mathrm{C}$ for $6 \mathrm{~h}$ and MP gels (after cooking) were completely mixed with 10 volumes of 5\% SDS solution, boiled for $10 \mathrm{~min}$, and centrifuged at $2,000 \times \mathrm{g}$ for $15 \mathrm{~min}$. The supernatant was used as soluble proteins and protein content was measured by Biuret method. The protein profile was analyzed by SDSPAGE (Laemmli, 1970). The separated profile of protein from MP mixture and MP gel were used for pattern of sample before and after cooking, respectively.

\section{MP gel characterization}

\section{Color measurement}

The colorimeter (CR-10, Minota Co. Ltd., Japan) calibrated with the white plate standard was used to measure the color of chicken MP gels. The hunter $L, a$, and $b$ values were reported.

\section{Cooking loss}

After storing at room temperature for $4 \mathrm{~h}$, chicken MP gels were carefully separated from the wall of vial to let the drain out of exudate. The amount of exudate was used to calculate the cooking loss as the percentage relative to the original weight of sample.

\section{Breaking force}

The breaking force of chicken MP gel after measuring the cooking loss was analyzed by a puncture test using an Instron Universal (Instron Corporation, USA). A puncture probe with diameter of $9 \mathrm{~mm}$ was used. Samples were compressed at the head speed of $50 \mathrm{~mm} / \mathrm{min}$ until reaching up to the penetration length was $1.2 \mathrm{~cm}$. Among the peaks, the first peak was recorded to be the breaking force.

\section{Microstructure}

The MP gels were cut into cubic shape $(3 \mathrm{~mm})$ before adding the $2.5 \%$ glutaraldehyde containing $0.1 \mathrm{M}$ sodium phosphate buffer $\mathrm{pH} 7.0$ overnight at $4^{\circ} \mathrm{C}$. Samples were rinsed with washing buffer $(0.1 \mathrm{M}$ sodium phosphate buffer $\mathrm{pH} 7$ ) for $10 \mathrm{~min}$ and post fixed with $1 \%$ osmium tetraoxide $\left(\mathrm{OsO}_{4}\right)$ for $5 \mathrm{~h}$. Then, the samples were washed 3 times (10 min/each) with washing buffer before dehydration by soaking in different concentrations of ethanol (10 $\mathrm{min} /$ each) ranging from 50, 60, 70, 80, 90, and 100\%. Thereafter, a $100 \%$ acetone was finally applied for $10 \mathrm{~min}$. The dried samples were lyophilized for overnight before performing the gold coating $(15 \mathrm{~nm})$ and microstructures ( $\times 2000)$ were taken at the accelerating voltage of $15 \mathrm{kV}$ (FE-SEM, JSM-7500F, JEOL Ltd., Japan).

\section{Statistical analysis}

The significant difference of treatments at confidential level $(p \leq 0.05)$ was considered for mean values, which was based on the ANOVA analysis using the PASW statistics 18 (SPSS Inc., USA).

\section{Results and Discussion}

\section{Solubility of SP and chicken MP}

Solubility of normal SP has been found to be approximately $55 \%(5.5 \mathrm{mg} / \mathrm{mL})$ when the original weight of powder was considered to be $100 \%$. This suggested that lyophilization induced the changes in protein structure, resulting in the protein aggregation. Thus, the interactions between protein and water were limited. However, normal SP showed the highest value when compared to other 
treated samples (Fig. 1(a)). It can be seen that solubility of the alkaline-treated SP was higher than that of acidtreated SP. Tadpitchayangkoon et al. (2010) found that application of acid or alkaline treatments induced fish SP denaturation and precipitation. Yongsawatdigul and Hemung (2010) also reported that application of the acid treatment to fish SP resulted in a drastic decrease in solubility to the greater extent than that of alkaline treatment. This result suggested that normal SP would be advantage for generating the functional properties since solubility of protein has been considered to be the prerequisite.

At a low salt concentration $(<0.15 \mathrm{M})$, chicken MP was not solubilized and it was started to increase with increased $\mathrm{NaCl}$ concentration from $0.3 \mathrm{M}$ and reaching up the maximal values at $0.6-0.9 \mathrm{M}$ (Fig. 1 (b)). $\mathrm{NaCl}$ was reported to be the prime factor governing the solubility of muscle proteins, directly affecting the protein-protein interactions. It can be noticed that $\mathrm{NaCl}$ at $0.3 \mathrm{M}$ was the lowest solubility of chicken MP (Dimitrakopoulou et al., 2005). This condition is considered to have a lower $\mathrm{NaCl}$ content in MP gel. Manufacturing the low salt protein gel has been considered to be the alternative way for launching healthy meat products for targeted consumers. However, the less reactive MP at low salt might be the limitation for generating the functionalities, especially the gelation. Cardoso et al. (2010) reported that addition of MTG pro-
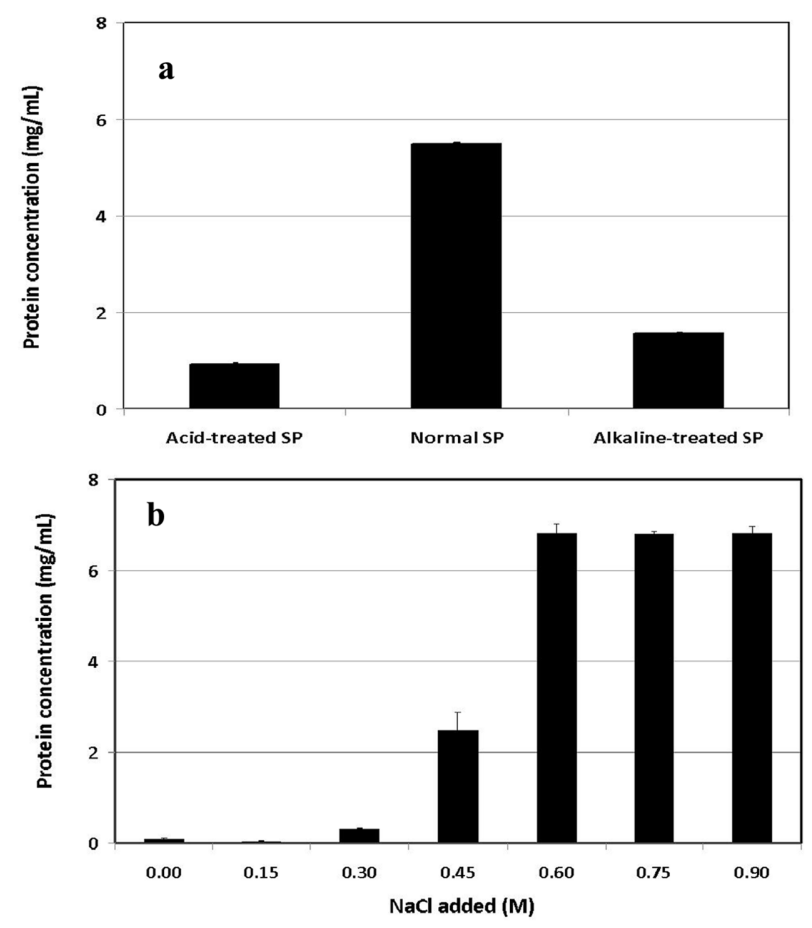

Fig. 1. Solubility of different types of SP (a) and chicken MP (b) as a function of $\mathrm{NaCl}$ concentration in $50 \mathrm{mM}$ phosphate buffer pH 6.25 . vided a satisfied texture of low salt protein gels. This allowed the preparation of the chicken MP gel at a low salt condition by addition of MTG.

\section{Rheological properties of MP}

The shear stress of MTG-mediated MP mixture from chicken increased upon increasing shear rate and the behavior belonged to the shear thinning type. The yield stress was observed at about $60 \mathrm{~Pa}$ (Fig. 2). It can be seen that the shear stress of MTG-mediated MP alone was lower than that with normal SP. This indicated that interaction between normal SP and chicken MP resulted in an increase viscosity, which was different from the previous report of Hemung and Chin (2013), who reported that the addition of fish SP in combined with fish MP was not different from each other. This might be partially due to the different species (fish vs chicken). However, shear stress of sample was further increased with adding acid-treated SP powder, which was comparable to that of alkalinetreated SP. Yongsawatdigul and Hemung (2010) reported that application of acid or alkaline treatments to SP resulted in improve water holding capacity. These implied that the acid- or alkaline- treated SP cause to the unfolded proteins and subsequently aggregate to form a stable matrix when the $\mathrm{pH}$ was adjusted to $\mathrm{pH} 7$, resulting in absorption of more water and might affect directly the viscosity of MP.

\section{SDS-PAGE of MP mixture/gel}

Protein patterns of MTG-mediated MP mixture (before cooking) at $0.30 \mathrm{M} \mathrm{NaCl}$ were analyzed by SDS-PAGE (Fig. 3). Protein cross-linking of myosin heavy chain (MHC) at $200 \mathrm{kDa}$ through the formation of covalent

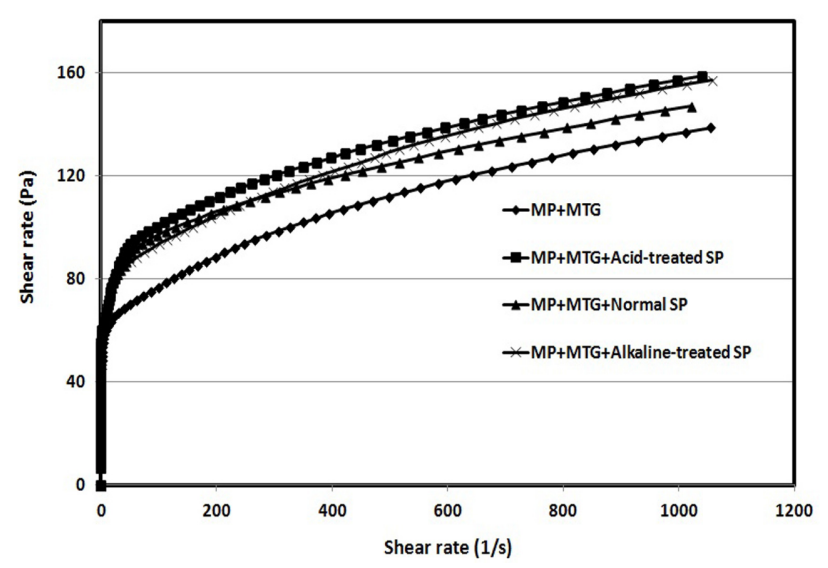

Fig. 2. Rheological properties of chicken MP mixture incubated at $4^{\circ} \mathrm{C}$ for $6 \mathrm{~h}$ induced by MTG with different types of SP at $0.30 \mathrm{M} \mathrm{NaCl}$. 


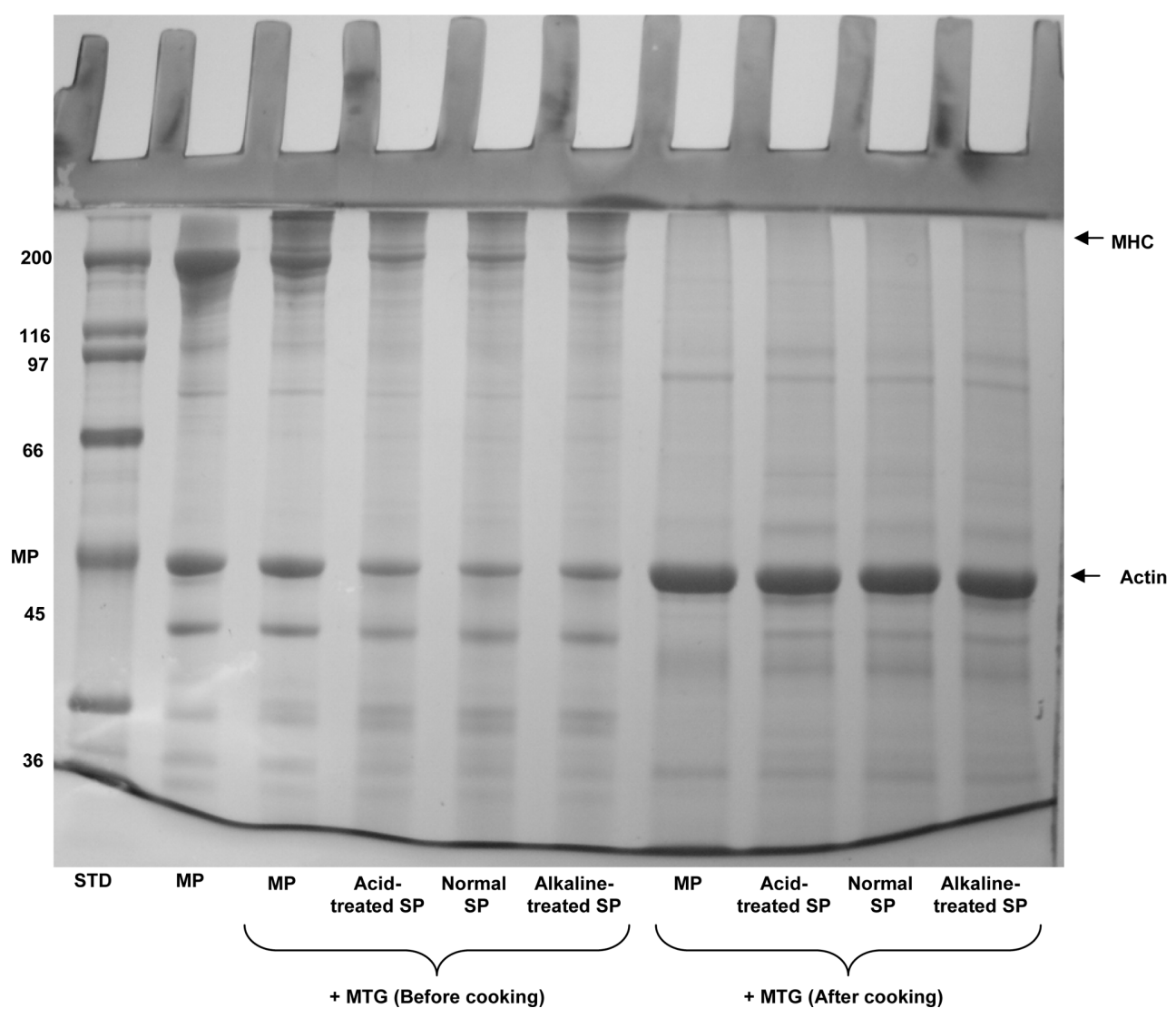

Fig. 3. SDS-PAGE profiles of chicken MP mixture/gel mediated by MTG prepared with different types of SP at $0.3 \mathrm{M}$ NaCl.

bonding formation was observed as evidenced by a slight decrease of MHC intensity up on adding MTG. The protein pattern of MP mixture before cooking was totally different from that after cooking. Although the MHC band was only disappeared partially in MP mixture (before cooking), it was completely disappeared in MP after cooking (MP gel). In addition, only actin band (at $45 \mathrm{kDa}$ ) was observed dominantly, suggesting that it was not cross-linked by the action of MTG.

It has been reported that MHC from chicken MP was the favorite substrate for MTG (Ahhmed et al., 2009). Our results suggested that MTG could be activated at low salt concentration $(0.3 \mathrm{M})$ even at a low incubation temperature when the incubation time is prolong to be $6 \mathrm{~h}$. Crosslinking of chicken MP catalyzed by MTG in the presence of non-meat protein increased with incubation time, although the solubility MP was limited by low $\mathrm{NaCl}$ concentration (Ramirez-Suarez and Xiong, 2003). As previously reported, the addition of SP did not change the protein profile of MP mixture, indicating that addition of the $\mathrm{pH}$-treated SP to chicken MP did not affect the crosslinking reaction catalyzed by MTG (Hemung and Chin, 2013: Park and Park 2007).

\section{DSC of MP mixture}

The changes in heat flow of the MTG mediated chicken MP mixture are shown in Fig. 4. The endothermic peak, corresponding to the thermal unfolding of chicken $\mathrm{MHC}$ in sample without SP was found at about $61^{\circ} \mathrm{C}$, which

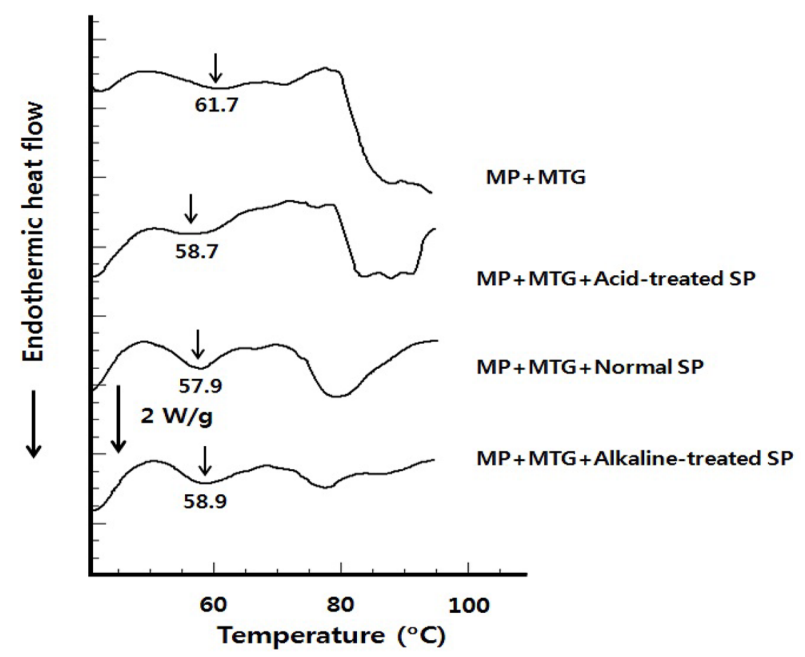

Fig. 4. Thermogram from the differential scanning calorimetry of chicken MP mixture incubated at $4^{\circ} \mathrm{C}$ for $6 \mathrm{~h}$ with MTG and different types of SP at $0.30 \mathrm{M} \mathrm{NaCl}$. 
was higher than the previous study using fish $\mathrm{MP}\left(53^{\circ} \mathrm{C}\right)$. However, this peak was decreased to be around $58^{\circ} \mathrm{C}$ when normal SP powders were added. This suggested that interactions between fish SP and chicken MP resulted in a decrease thermal stability of protein, as supported by Chaijan et al. (2008) who reported that myoglobin could react with MHC within MP. Furthermore, the addition of $\mathrm{pH}-$ treated fish SP into chicken MP reduced the endothermic peak and similar to those of normal SP addition. Muscle protein having the low thermal stability is unfold easily and is also susceptible to interact with others, promoting protein-protein interactions during heating. Thus, the addition of SP into the chicken MP might be advantageous to the functional properties, regardless of $\mathrm{pH}$ treatment.

\section{Characteristics of MP gel}

\section{Cooking loss}

The cooking loss value of MTG-mediated MP from chicken decreased significantly $(p \leq 0.05)$ after adding the normal SP. Cooking loss of fish MP was reduced for about $32 \%$ when fish SP powder was added at $0.5 \%$ (Hemung and Chin, 2013). Application of $\mathrm{pH}$-treated SP samples in this system supposed to reduce the cooking loss to the higher level since they could hold more water as evidence by high viscosity. However, it turns to be that the cooking loss of chicken MP gel in the presence of $\mathrm{pH}$-treated SP and normal SP were similar. This result suggested that the mechanism to reduce the cooking by two types of SP were different. It is possible to explain that the insoluble matrix within the $\mathrm{pH}$-treated SP samples started to absorb water upon mixing, resulting in the swollen molecule, as indicated by high viscosity (Fig. 2). Such swollen molecules would participate in a reduction of cooking loss in MP gel. For normal SP, water could be trapped in the gel structure through the miscibility of soluble SP and MP complex. Those complexes would participate in building the strong network during gelation. Such strong gel net- works were found in fish protein gel when fish SP were added (Jafarpour and Gorczyca, 2009). Our results also demonstrated that fish SP has a potential for being the alternative source of the water holding agent for chicken or poultry.

\section{MP gel color}

The lightness ( $L$ value) of the gel was increase slightly by addition of normal SP (Table 1). Our results were not in agreement with previous study (Jafarpour and Gorczyca, 2009), which reported that the lightness of surimi gel was decreased up on adding SP. Perez-Alvarez et al. (1999) reported that a reduction of lightness in meat products was due to moisture lost. This might be partially due higher water hold with normal SP in this study. However, $\mathrm{pH}$-treated SP did not affect the gel lightness. Although addition of acid- and alkaline-treated SP could not increase the lightness of MP gel, the negative values of hunter $a$ and $b$ values were observed. The redness ( $a$ value) of the MP gel incorporated with SP powders was decreased $(p<0.05)$. Ramirez et al. (2007) found that addition of recovered solid from the washed water, generated by surimi plant, for $5 \%$ into surimi resulted in a reduction of the redness. This might be partially due to the dilution effect since the white SP was added into chicken MP. The yellowness ( $b$ values) of the MP gels was not affected by SP samples. Base on the color measurement, addition of normal or $\mathrm{pH}$-treated $\mathrm{SP}$ would be possible since the negative effect on the lightness was not observed.

\section{Breaking force of MP}

Gelation of chicken MP at the low $\mathrm{NaCl}$ concentration was formed successfully when MTG was added, allowing the measurement of breaking force of MP gel. Uresti et al. (2004) applied MTG to improve the textural properties of the low-salt restructured fish products. These results suggested that MTG was the promising ingredient to improve textural properties of protein gel at low salt condi-

Table 1. Properties of MTG-mediated MP gels from chicken prepared with different types of SP

\begin{tabular}{|c|c|c|c|c|}
\hline \multirow[b]{2}{*}{ Properties } & \multicolumn{4}{|c|}{ Treatments } \\
\hline & $\mathrm{MP}+\mathrm{MTG}$ & $\begin{array}{c}\text { MP+MTG+ } \\
\text { Acid-treated SP }\end{array}$ & $\mathrm{MP}+\mathrm{MTG}+$ Normal SP & $\begin{array}{c}\text { MP+MTG+ } \\
\text { Alkaline-treated SP }\end{array}$ \\
\hline Cooking loss (\%) & $28.46 \pm 0.10^{\mathrm{a}}$ & $25.74 \pm 0.43^{b}$ & $25.97 \pm 0.20^{b}$ & $25.71 \pm 0.29^{b}$ \\
\hline Breaking force (gf) & $241.20 \pm 12.44^{\mathrm{d}}$ & $307.17 \pm 17.43^{\mathrm{c}}$ & $362.45 \pm 12.24^{\mathrm{a}}$ & $334.32 \pm 12.39^{b}$ \\
\hline Hunter $L$ value & $80.7 \pm 2.6^{\mathrm{b}}$ & $80.4 \pm 1.7^{b}$ & $82.0 \pm 1.8^{\mathrm{a}}$ & $80.6 \pm 1.9^{\mathrm{b}}$ \\
\hline Hunter $a$ value & $-0.4 \pm 1.2^{\mathrm{a}}$ & $-0.8 \pm 1.4^{\mathrm{b}}$ & $-0.8 \pm 1.3^{b}$ & $-0.9 \pm 1.5^{b}$ \\
\hline Hunter $b$ value & $-4.9 \pm 1.2^{\mathrm{a}}$ & $-4.5 \pm 1.0^{\mathrm{a}}$ & $-4.5 \pm 0.8^{a}$ & $-4.7 \pm 1.0^{\mathrm{a}}$ \\
\hline
\end{tabular}

Mean \pm SE was calculated based on at least 4 replications.

${ }^{\mathrm{a}, \mathrm{b}}$ Different letters in the same row are statistically different $(p \leq 0.05)$. 
tion. Cardoso et al. (2010) suggested that the high textural properties of protein gels could be produced by addition of MTG although the $\mathrm{NaCl}$ was reduced to be $1 \%$.

It can be clearly seen that the breaking force of MTGmediated MP gels was increased upon adding the acidtreated SP and a further improvement was observed when alkaline-treated SP was incorporated $(p<0.05)$ (Table 1). Moreover, the highest breaking force was found in sample mixed with normal SP. This finding was in agreement with Jafarpour and Gorczyca (2009), who found that the addition of SP from common carp into surimi resulted in an increases of gel strength. In addition, SP (5\%) could improve gel strength of MP gel from rock fish (Kim et al., 2005). Moreover, adding recovered proteins from surimi wash water resulted in an improvement of textural properties (Ramirez et al., 2007). It can be noticed that the thermal stability of MP system was lower when all types of SP was incorporated (Fig. 3). This suggested that the thermal stability of protein mixture/complex was the prime factor governing the gelation as well as textural properties of chicken MP gel.

The breaking force of MP gels mixed with acid- and alkaline-treated SP samples was improved to the lesser extent than that of normal SP. In addition, the different protein pattern of MP was not observed among different types of SP (Fig. 3). This suggested that the different in breaking force might not be due to the action of remaining protease residues. However, the lower breaking force might be from the different solubility since that value of pH-treated SP was lower than that of normal SP (Fig. 1a). The high soluble proteins from normal SP would likely more facilitate in gelation. Thus, the less soluble protein from $\mathrm{pH}$-treated SP leaded to the limitation of gelation process. In addition, MP gel with alkaline-treated SP, which had higher solubility, showed higher breaking force than that with acid-treated SP (lower solubility). This finding was strongly indicated that the solubility of SP was one of factor, affecting the improvement of textural properties of MTG-mediated MP gel. Based on the results, normal SP could be the most effective ingredient to improve textural properties as well as reduce cooking loss for chicken protein gel. Although subjecting SP to the $\mathrm{pH}$ treatments prior adding into MP resulted in lesser improvement of gel strength but this treatment show a

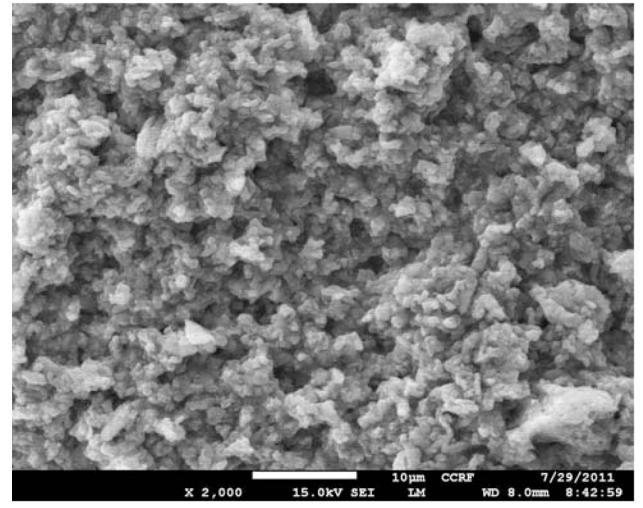

c

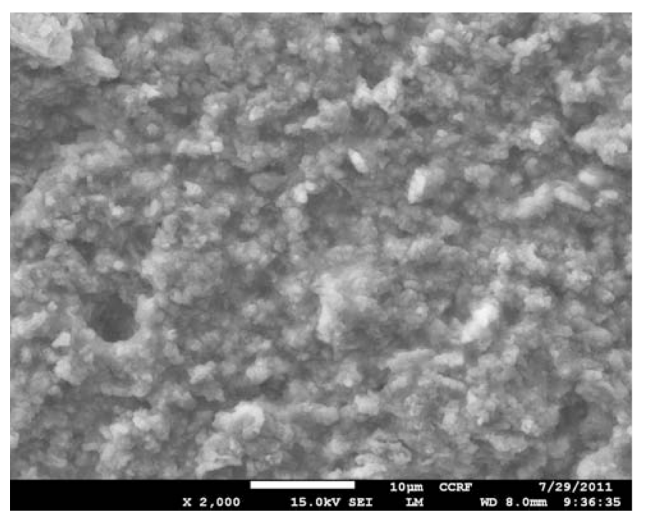

b

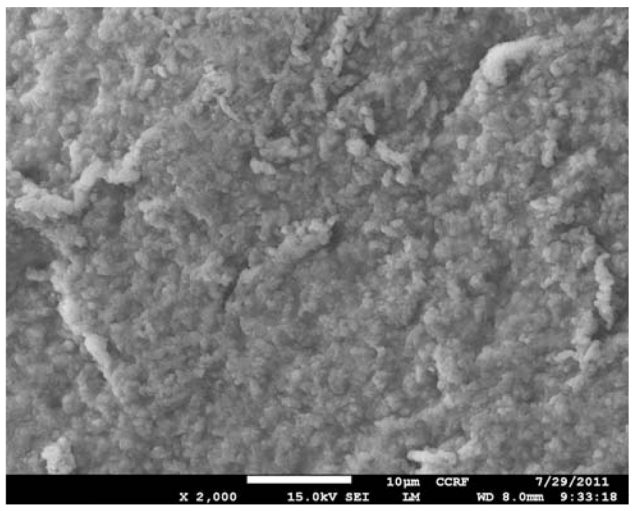

d

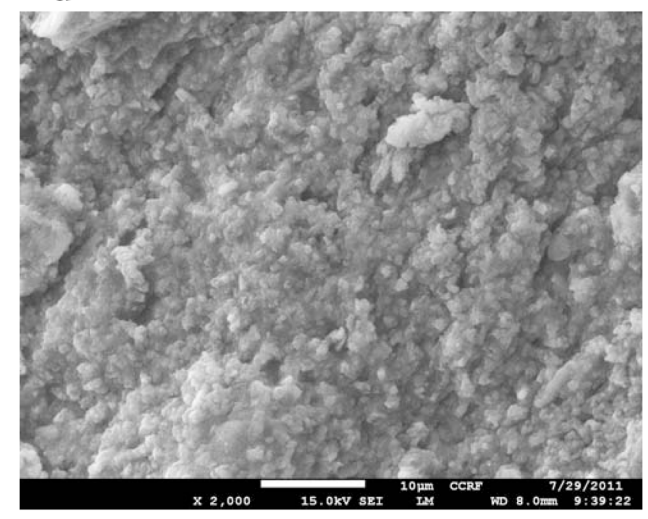

Fig. 5. Microstructure $(\times 2000)$ of MTG-mediated chicken MP gels prepared with different types of SP $(0.5 \%)$. (a) $=$ MP $+M T G$, (b) $=$ MP+MTG+Acid-treated SP, (c) $=$ MP+MTG+Normal SP, and (d)=MP+MTG+Alkaline-treated SP. 
more facilitate in protein recovery. Protein in solution could be precipitated and recovered easily by $\mathrm{pH}$-treatment. Then, recovered protein could be use as the water holding agent without affecting the adverse affect on textural properties.

\section{Microstructure}

Microstructures of MTG-mediated chicken MP gels alone showed the rough structure, which was clearly different from that with normal SP (Fig. 5(a) and (c)). In addition, microstructure of chicken MP gel incorporated with fish SP showed the smooth structure, regardless of the treatment of SP, corresponding with the comparable in a reduction of cooking loss (Table 1). Therefore, the smooth and swollen structure would be participated in water retention, leading to a reduction of cooking loss of the protein gel. The soluble protein in normal SP would likely miscible with MP, building the smooth structure, which was also observed when SP was added into surimi gel (Jafarpour and Gorczyca, 2009). There was no significantly different microstructure among MP gels, regardless the types of SP added. This could be explained why all SP could reduce the cooking loss to the comparable extent. Based on the microstructure, the smooth gel network of chicken MP gels would hold more water, leading to a reduction of cooking loss of MTG-mediated MP gel.

\section{Conclusions}

Heat-induced gelation of chicken MP at $0.30 \mathrm{M} \mathrm{NaCl}$ could be induced successfully by adding MTG. The cooking loss of MTG-mediated MP gel was reduced significantly by adding fish SP, regardless the $\mathrm{pH}$ treatment. Breaking force of MP gel was increased by adding $\mathrm{pH}-$ treated SP and the normal SP was most effective. The lightness of MP gel was increased by adding normal SP, while it was not affected by adding $\mathrm{pH}$-treated SP. The redness was decreased with the addition of SP, regardless of $\mathrm{pH}$ treatment, while the yellowness was unaffected. In conclusion, application of fish SP in chicken MP gel mediated by MTG could improve textural properties as well as reduce cooking loss. In addition, acid and alkaline treatment effectively improved the gel strength in chicken MP gels.

\section{Acknowledgements}

This study was financially supported by Chonnam National University, 2012.

\section{References}

1. Ahhmed, A. M., Kuroda, R., Kawahara, S., Ohta, K., Nakade, K., Aoki, T., and Muguruma, M. (2009) Dependence of microbial transglutaminase on meat type in myofibrillar protein cross-linking. Food Chem. 112, 354-361.

2. Ando, H., Adachi, M., Umeda, K., Matsuura, M., Nonaka, M., Uchio, R., Tanaka, H., and Motoki, M. (1989) Purification and characteristics of novel transglutaminase derived from microorganisms. Agric. Biol. Chem. 53, 2613-2617.

3. AOAC (2000) Meat and meat products - Method 950.46.991. 36. Maryland, USA. pp.1, 3, 7-8.

4. Cardoso, C., Mendes, R., Vaz-pires, P., and Nunes, M. L. (2010) Effect of salt and MTG on the production of high quality gels from farmed sea bass. J. Food Eng. 101, 98-105.

5. Chaijan, M., Benjakul, S., Visessanguan, W. Lee, S., and Faustman, C. (2008) Interaction of fish myoglobin and myofibrillar proteins. J. Food Sci. 73, C292-298.

6. Dimitrakopoulou, M. A., Ambrosiadis, J. A., Zetou, F. K., and Bloukas, J. G. (2005) Effect of salt and transglutaminase (TG) level and processing conditions on quality characteristics of phosphate-free, cooked, restructured pork shoulder. Meat Sci. 70, 743-749.

7. Folk, J. E. (1980) Transglutaminase. Ann. Rev. Biochem. 49, 517-531.

8. Gornall, A. G., Bardawill, C. J., and David, M. M. (1949). Determination of serum proteins by means of the biuret reaction. J. Biol. Chem. 177, 751-766.

9. Hemung, B. and Chin, K. B. (2013) Effects of fish sarcoplasmic proteins on the properties of myofibrillar protein gels mediated by microbial transglutaminase. LWT. Food Sci. Tech. 53, 184-190.

10. Hong, G. P. and Chin, K. B. (2010) Effect of microbial transglutaminase and sodium alginate on cold set gelation of porcine myofibrillar protein with various salt levels. Food Hydrocolloid. 24, 444-451.

11. Jafarpour, A. and Gorczyca, E. M. (2009) Characteristics of sarcoplasmic proteins and their interactions with surimi and kamaboko gel. J. Food Sci. 74, N16-N22.

12. Karthikeyan, K., Mathew, S., Shamasundar, B. A., and Prakash, V. (2004) Fractionation and properties of sarcoplasmic proteins from oil sardine (Sardinella longiceps): Influence on the thermal gelation behavior of washed meat. J. Food Sci. 69, 79-83.

13. Kim, Y. S., Yongsawatdigul, J., Park, J. W., and Thawornchinsombut, S. (2005) Characteristics of sarcoplasmic proteins and their interaction with myofibrillar proteins. J. Food Biochem. 29, 517-531.

14. Krasaechol, N., Sanguandeekul, R., Duangmal, K., and Owusu-Apenten, R. K. (2008) Structure and functional properties of modified threadfin bream sarcoplasmic protein. Food Chem. 107, 1-10.

15. Laemmli, U. K. (1970) Cleavage of structural proteins during the assembly of the head of bacteriophage T4. Nature 227, 680-685.

16. Lin, T. M., Park, J. W., and Morrissey, M. T. (1995) Recov- 
ered proteins and reconditioned water from surimi processing waste. J. Food Sci. 50, 4-9.

17. Park, J. D. and Park, J. W. (2007) Extraction of sardine myoglobin and its effect on gelation properties of Pacific whiting surimi. J. Food Sci. 72, C202-206.

18. Perez-Alvarez, J. A., Sayas-Barbera, M. E., Fernandez-Lopez, J., and Aranda-Catala, V. (1999) Physicochemical characteristics of Spanish-type dry-cured sausage. Food Res. Inter. 32, 599-607.

19. Pietrasik, Z., Jarmoluk, A., and Shand, P. J. (2007) Effect of non meat proteins on hydration and textural properties of pork meat gels enhanced with microbial transglutaminase. LWT. Food Sci. Tech. 40, 915-920.

20. Ramirez, J. A., Velazquez, G., Echevarria, G. L., and Torres, J. A. (2007) Effect of adding insoluble solids from surimi wash water on the functional and mechanical properties of pacific whiting grade A surimi. Biores. Tech. 98, 2148-2153.

21. Ramirez-Suarez, J. C. and Xiong, Y. L. (2003) Effect of transglutaminase-induced cross-linking on gelation of myofibrillar/soy protein mixtures. Meat Sci. 65, 899-907.

22. Ruiz-Carrascal, J. and Regenstein, J. (2002) Emulsion stabil- ity and water uptake ability of chicken breast muscle proteins as affected by microbial transglutaminase. J. Food Sci. 67, 734-739.

23. Tadpitchayangkoon, P., Park, J. W., and Yongsawatdigul, J. (2010) Conformational changes and dynamic rheological properties of fish sarcoplasmic proteins treated at various $\mathrm{pHs}$. Food Chem. 121, 1046-1052.

24. Uresti, R. M., Téllez-Luis, S. J., Ramirez, J. A., and Vázquez, M. (2004) Use of dairy proteins and microbial transglutaminase to obtain low-salt fish products from filleting waste from silver carp (Hypophthalmichthys molitrix). Food Chem. 86, 257-262.

25. Xiong, Y. L. (1993) A comparison of the rheological characteristics of different fractions of chicken myofibrillar proteins. J. Food Biochem. 16, 217-227.

26. Yongsawatdigul, J. and Hemung, B. (2010) Structural changes and functional properties of threadfin bream sarcoplasmic proteins subjected to $\mathrm{pH}$-shifting treatments and lyophilization. J. Food Sci. 75, C251-257.

(Received 2014.1.15/Revised 2014.3.17/Accepted 2014.4.21) 